\title{
5 Research Square

\section{Ethnobotanical Study of Medicinal Plants in Hidabu Abote District, North Shewa Zone, Oromia Region, Ethiopia}

Boja Tilinti Bose ( $\sim$ bojatilinti55@gmail.com )

Madda Walabu University https://orcid.org/0000-0002-6164-9116

Yoseph Melka

Hawassa University

Tesfaye Awas

EBI: Ethiopian Biodiversity Institute

\section{Research}

Keywords: Aliments, Ethnobotany, Human disease, Livestock disease

Posted Date: March 31st, 2021

DOl: https://doi.org/10.21203/rs.3.rs-338768/v1

License: (c) (1) This work is licensed under a Creative Commons Attribution 4.0 International License.

Read Full License 


\section{ETHNOBOTANICAL STUDY OF MEDICINA L PLANTS IN HIDABU ABOTE DISTRICT, NORTH SHEWA ZONE, OROMIA REGION, ETHIOPIA Boja Tilinti $(\mathrm{MSc})^{1} \quad$ Yoseph Melka $(\mathrm{PhD})^{2} \quad$ Tesfaye Awas $(\mathrm{PhD})^{3}$ \\ Madda ${ }^{1}$ Walabu University Hawassa University ${ }^{3}$ Ethiopian Biodiversity Institute bojatilinti55@gmail.com yosef.melka@gmail.com tesfayeawas@gmail.com}

\section{ABSTRACT}

Background: The world population use medicinal plants for treating diseases in forms of drug developments also traditional medicinal specially developing countries. The economic growth and cultural changes threaten the traditional lifestyle of local people. The aim of the study is to investigate medicinal plants and associated indigenous knowledge.

Methods: Ethnobotanical data were obtained using semi-structured interviews, focus group discussion and market survey. Data were analyzed by descriptive statistics, informant consensus factor, preference ranking and Direct matrix ranking using Microsoft Excel and Statistical Package for Social Science Version 20.

Results: Ethnomedicinal use of 136 medicinal plant species belonging to 117 genera and 63 families wereidentified and documented. The highest number of medicinal plants was used in midland kebele(74 species). Out of total medicinal plants 66 (48.53\%) species were reported to treat human aliments only. Most of the medicinal plants harvested were herbs $(37.50 \%)$, followed by trees $(36.76 \%)$ and the least was lianas $(0.74 \%)$. A Pearson correlation test indicated a positive and significant difference between age of informants and number of medicinal plant species cited, and negative and significant difference between level of education and number of medicinal plant species cited. The result indicates that there was significant difference between male and female informants in their knowledge of medicinal plants, and there was significant different between number of medicinal plants reported by key informants and household respondents. Cordia africana ranked first as a multipurpose medicinal plant. Agricultural expansion (41.96\%) stood first as a factor threatening medicinal plants.

Conclusion: The highest numbers of MPs were used in Sire Morose kebele (midland), but collection was not restricted only to their locality the move other kebeles to harvest MPs. In the study area elders have better knowledge of medicinal plant than younger and as people educate their knowledge on medicinal plants decrease.. This implies that in study area there is potential indigenous knowledge but we are going loss this traditional knowledge if did not develop means transferring this to next generation. To support local people effort on in-situ conservation and ex-situ conservation needed.

Key words: Aliments, Ethnobotany, Human disease, Livestock disease 


\section{INTRODUCTION}

Ethnobotany is a broad term referring to the study of the relationship between peoples, plants and the environment involving wide range of disciplines with particular emphasis on traditional cultures (Martin, 1995; Cotton, 1996). Over centuries, local peoples of different localities have advanced their own specific knowledge on plant resource uses, management and conservation (Cotton, 1996). Indigenous knowledge of medicinal plants and their use by indigenous cultures are not only beneficial for conservation of cultural traditions and biodiversity, but also healthcare and drug development in the present and upcoming day (Tamiru et al., 2013).

The world primary means of treating diseases and fighting infections has been based on the use of medicinal plant species. From ancient times, plants have been rich sources of effective and safe medicines (Russell et al., 2006). Globally, about $64 \%$ of the total world population is reliant on traditional medicine for their healthcare needs (Phondani et al., 2016). According to the World Health Organization (WHO), nearly 3.5 billion people in developing countries believe in the efficiency of plant remedies and use them regularly (WHO, 2003).

In Ethiopia, over $80 \%$ of the population was relies on traditional medicines (Abebe and Ayehu, 1993; Tadesse et al., 2005; Bekele, 2007). In Ethiopia, plants have shown very effective medicinal value for some diseases of humans and livestock ${ }^{e e} s$. The major reasons why medicinal plants are demanded in Ethiopia are due to culturally associated traditions, the trust of communities on medicinal values of traditional medicines and relatively low cost in using them (Tadesse et al., 2005; Bekele, 2007).

Ethiopia is a country with various types of climatic, topographic, soil features and agroecological zones (Institute of Biodiversity Conservation, 2005). This makes the country to have a rich and diverse fauna and flora. But little emphasis has been given to ethnobotanical studies over the earlier periods (Dawit, 2001), while there are some attempt in investigating medicinal plants and indigenous knowledge on sustainable use of plant resources.

According to Lulekal et al. (2008), the current loss of medicinal plants in the country due to natural and anthropogenic factors linked with the loss of valuable indigenous knowledge associated with the plants.

Awas (2007) noted that detailed information on medicinal plants of Ethiopia could only be acquired when studies are undertaken in several parts of the country where little or no botanical and ethnobotanical explorations have been conducted. Lack of documentation and under reporting of ethnomedicinal plant knowledge are some of the major problems of traditional 
medicine in Ethiopia (Yineger and Yewhalaw, 2007; Birhanu, 2013). In the Hidabu Abote district there is gap in the documentation of medicinal plants and associated indigenous knowledge. Moreover, it is necessary to find solution that the new generations underutilization of medicinal plants by focusing on modern medicine.

The overall aim of the study is to investigate medicinal plants and associated indigenous knowledge. In addition to identify the threats and conservation practices applied for medicinal plants use in the study area.

\section{METHODS}

\section{Description of the study area}

The study was conducted in the Hidabu Abote district, North Shewa zone of Oromia regional state. The districtes capital Ejere is $146 \mathrm{~km}$ away from Addis Ababa. The district is divided into 20 kebeles where 19 of them are rural and one of them is urban kebele (HADANRO, 2016).

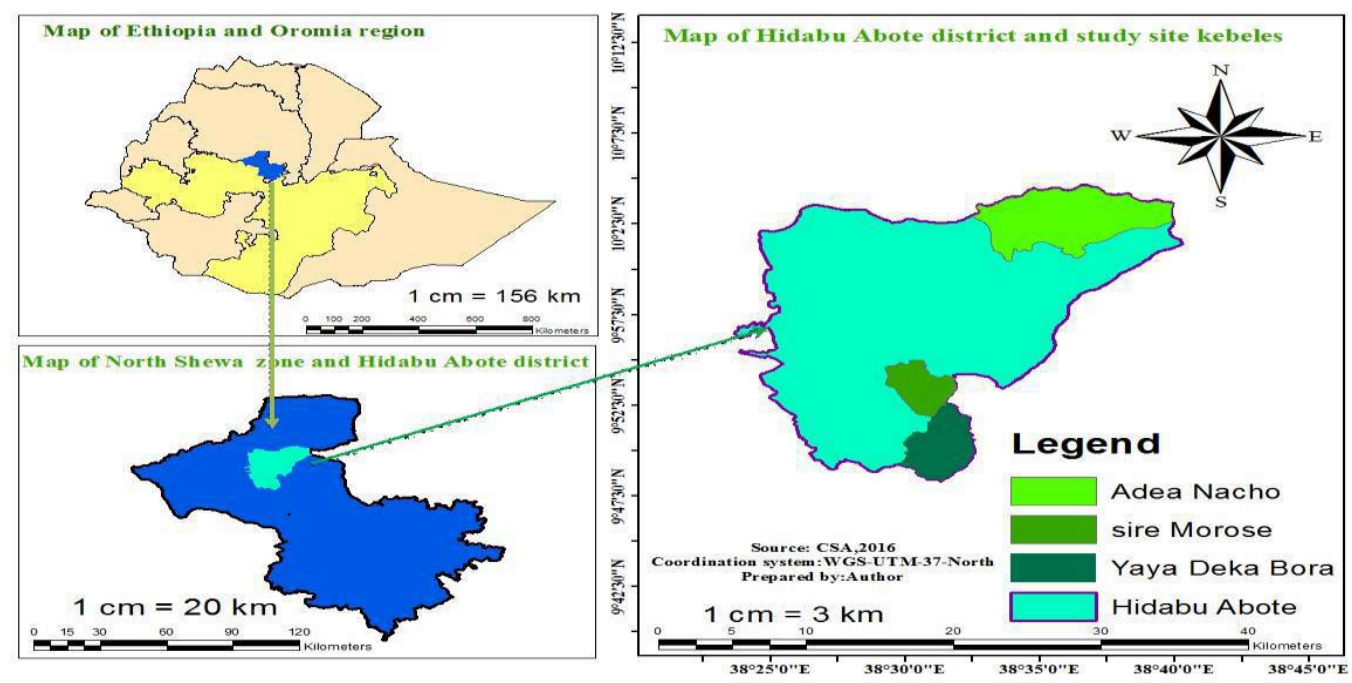

\section{Methods of data collection}

Before starting the actual field study, reconnaissance survey was conducted to obtain information about socio-economic characteristics of local people and indigenous agroclimatic classification of kebeles in the district. The agroclimatic zones of the district are „Baddaa (highland) which ranges between 2,400-2,900mabsl, „Badda Daree' (midland) ranges from 2,100- 2,400mabsl, while „Gammojjiie (lowland) which range in altitude from 1,600-2,100mabsl. This variation in altitude resulted in variability in climate and vegetation types. Based on the information obtained during reconnaissance survey, kebeles were stratified to three agroclimatic zones (highland, midland and lowland); three sample kebeles were purposively selected from three strataees 
depending on the proximity to forest and availability of traditional healers. Adea Nacho (lowland), Sire Morose (midland) and Yaya Deke Bora (highland) kebeles were selected.

Sample respondents were selected from each selected kebeles randomly after list of household was obtained from kebele administrative offices. 20 key informants were selected from traditional healers and knowledgeable informants by snowball method.

The sizes of household respondents sample were calculated by using the following formula (Espinosa et al., 2012).

$$
n=\frac{N P(1-P)}{\left.(N-1)\left(d / z_{\mathrm{ox} / \mathrm{z}}\right)^{2}\right)+P(1-P)}
$$

Using the above formula the calculated representative sample size were 102 households, when non-respondent $10 \%$ (10), and the actual sample size were 112. Selected key informants were 20 from selected kebeles. Totally 132 informant households were selected for the study.

Ethnobotanical data were collected from December 20, 2016 to February 20, 2017 on two field trips made to the site. First field trip was to collect primary ethnobotanical data. The second field trip was conducted in order to confirm ethnobotanical information and to request people participated in study to indicate the wild plants they used to treat human and livestock aliments (Martin, 1995; Cotton, 1996). Accordingly, semi-structured interviewees, focus group discussions, and guided field walks with informants were employed.

Semi-structured interviews were conducted based on a checklist of questions prepared beforehand in English, and translated to local language ,Afaan Oromoo'. Information regarding local names of medicinal plants, plant part(s) used, methods and conditions of preparation, diseases treated, dosage used, route of administration, and uses other than medicinal values, threats and conservation practices to medicinal plants were recorded at the spot. Observations were made on the morphological features and habitats of each medicinal plant species in the guided field walk.

Three focus group discussions undertaken in different agroclimatic zones with household respondents which have 6 members were conducted to understand indigenous classification of agroclimatic zones, medicinal plant uses; factors threaten medicinal plant species and conservation practiced.

Plant identification was performed both in the field and at the Ethiopian Biodiversity Institute (EBI). Plant specimens were deposited in the herbaria of EBI and Wondo Genet College of Forestry and Natural Resources herbarium. 


\section{Data analysis}

Descriptive statistics such as percentage and frequency using MS Excel spreadsheet 2010 were employed to summarize the data on medicinal plants use and associated indigenous knowledge. Statistical Package for Social Science (SPSS) Version 20 was used to summarize Pearson correlation relationship and to compare mean t-test.

Informant consensus factor (ICF) was calculated for each category to identify the agreements of the informants on the reported cures for the group of ailments (Heinrich et al., 1998).

$$
\text { ICF }=\frac{n u r-n t}{n u r-1}
$$

Preference ranking was conducted following the methods of Martin (1995), to rank some selected medicinal plants based on degree of their effectiveness in treating febrile illness human disease and blackleg livestock disease.

Direct matrix ranking was conducted in order to compare multipurpose medicinal plants commonly reported by informants following Cotton (1996).

\section{RESULTS AND DISCUSSION}

\section{Medicinal Plants in Hidabu Abote district}

A total of 136 medicinal plant species (Appendix) belonging to 117 genera and 63 families were identified in study the area. The number of medicinal plant species reported were higher than that of recorded to the Debre Libanos district by Getaneh and Girma (2014) where 83 medicinal plants were identified but, less than the studies carried out around Fiche district by Enyew et al. (2014) who reported 155 medicinal plant species. This observation shows that the local peoples in Hidabu Abote district have relatively extensive knowledge of how to use plants as medicine against different diseases. Out of the reported medicinal plants, 59 species were also reported by Enyew et al. (2014) and 37 species were reported by Getaneh and Girma (2014).

With regard to plant family, Fabaceae was the most popular to the area and, were represented by 13 species $(9.56 \%)$ and followed by Asteraceae 11 species (8.09\%), Laminaceae 8 species (5.88\%) and Solanceae 8 species $(5.88 \%)$. The finding agrees with other studies in Ethiopia (Alebie and Mehamed, 2016; Kebebew, 2016) and other countries (Tugume et al., 2016), in which Fabaceae was the dominant.

People in Hidabu Abote district responds that they have also cultural and spiritual related medicinal plant harvesting day, Tikimt $17^{\text {th }}$ ( October $27^{\text {th }}$ ) they believe that all plant species harvested in this day used for treatment of ailments. They call medicinal plants harvested in this 
day as "Qorichaa Estifaanoosii" (Estifanos medicine) especially reported to be used to treat febrile illness.

Out of the total identified medicinal plants 66 species $(48.53 \%)$ were reported to be used to treat human ailments only, 59 species (43.38\%) to treat both human and livestock, and 11 species $(8.09 \%)$ used to treat livestock ailments only. This result indicates that most of medicinal plants used for humans ailments as reported by different authors in medicinal plant studies carried out elsewhere (Lulekal et al., 2008; Getaneh and Girma, 2014; Kassa et al., 2016).

The highest number of medicinal plants were reported to be used in Sire Morose kebele (74 species), followed by Adea Nacho (70 species) and the least number of medicinal plants were used in Yaya Deka Bora kebele (57 species).

Most of medicinal plants were collected from the wild that collection of medicinal plants not limited to the kebeles they live in, they also harvest from other kebeles in the district. Medicinal plants collected from Jema valley mainly collected in the morning because in most cases the plants were obtained from far distances, secondly early in the morning snakes could not be encountered due to low temperatures and thirdly they believe that those medicinal plants effective only when they were collected in the morning and they reported that they culturally prefer only Wednesday and Friday morning and this in line with work of (Okello et al., 2010).

\section{Habitat and growth form of medicinal plants in Hidabu Abote district}

Of the total 136 medicinal plant species ( 87 species, 63.97\%) were collected from wild alone, (25 species, 18.38\%) were collected from both homegarden and wild, (13 species, 9.56\%) were collected from homegarden alone and (11 species, 8.09\%) were collected from farmland. This finding agrees with the Kassa et al. (2016); Fenetahun and Eshetu (2017) in which most of medicinal plants were collected from the wild than homegarden and farmland. The finding shows that local people in study area mostly depends on wild sources than homegarden and farmland to obtain medicinal plants. This indicates that negative influences on medicinal plant species that consequence to over-harvesting from wild and less conservation done for them and not as that of medicinal plants in homegarden, finally cause to shrinking medicinal plant species.

Among the 136 medicinal plant species recorded from the study area the highest representation was for herbs, which accounts for $51(37.50 \%)$ species, followed by trees $50(36.76 \%)$ and the least was liana, which for $1(0.74 \%)$ species (Figure 1). This finding agrees with previous studies by Awas and Demissew (2009); Enyew et al. (2014); Kebede et al. (2016) who reported dominance of herbs for medicinal purpose. This could be related to the fact that these species exhibit 
high level of abundance and easy to obtain them in homegarden and small patches of forest.

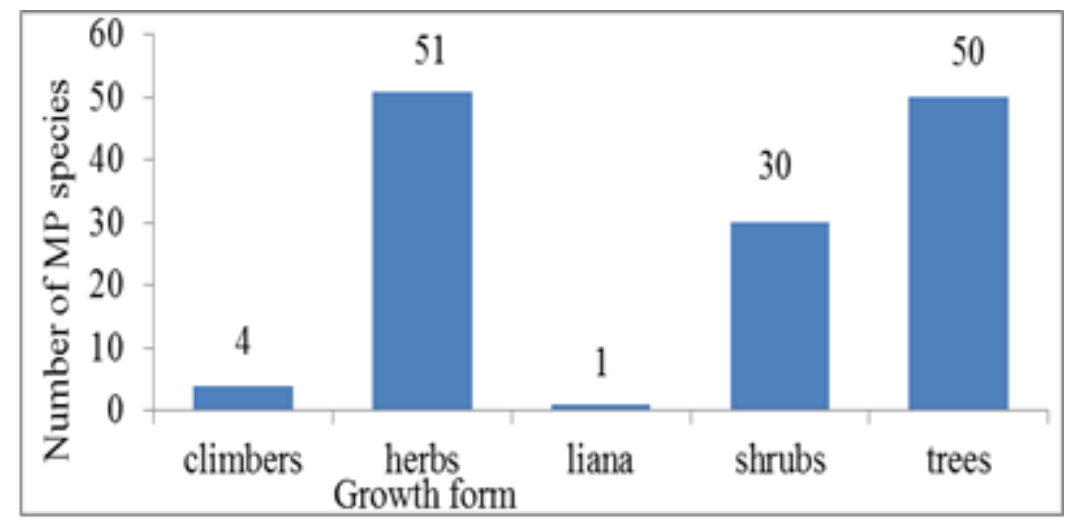

Figure 1: Growth form of MPs in the study area

\section{Parts used, mode of preparation, routes of administration and dosage of medicinal plants}

People in Hidabu Abote district were used different part(s) of medicinal plants for preparation of medicines to treat human and livestock aliments. Root parts of medicinal plants were the most frequently reported to be used in study area (35 species, 25.74\%), followed by leaves (33 species, 24.26\%), roots and leaves (13 species 9.56\%), seeds (12 species, 8.82\%) (Figure 2). Other finding in Ethiopia (Lulekal et al., 2008; Limenih et al., 2015) and other countries (Okello et al., 2010) also approve that root parts of medicinal plants mostly used for traditional medicine preparation. However, the uprooting of plants effect mother trees and causes totally death of plants. Excessive use of leaves also have negative affect on survival and regeneration of medicinal plants.

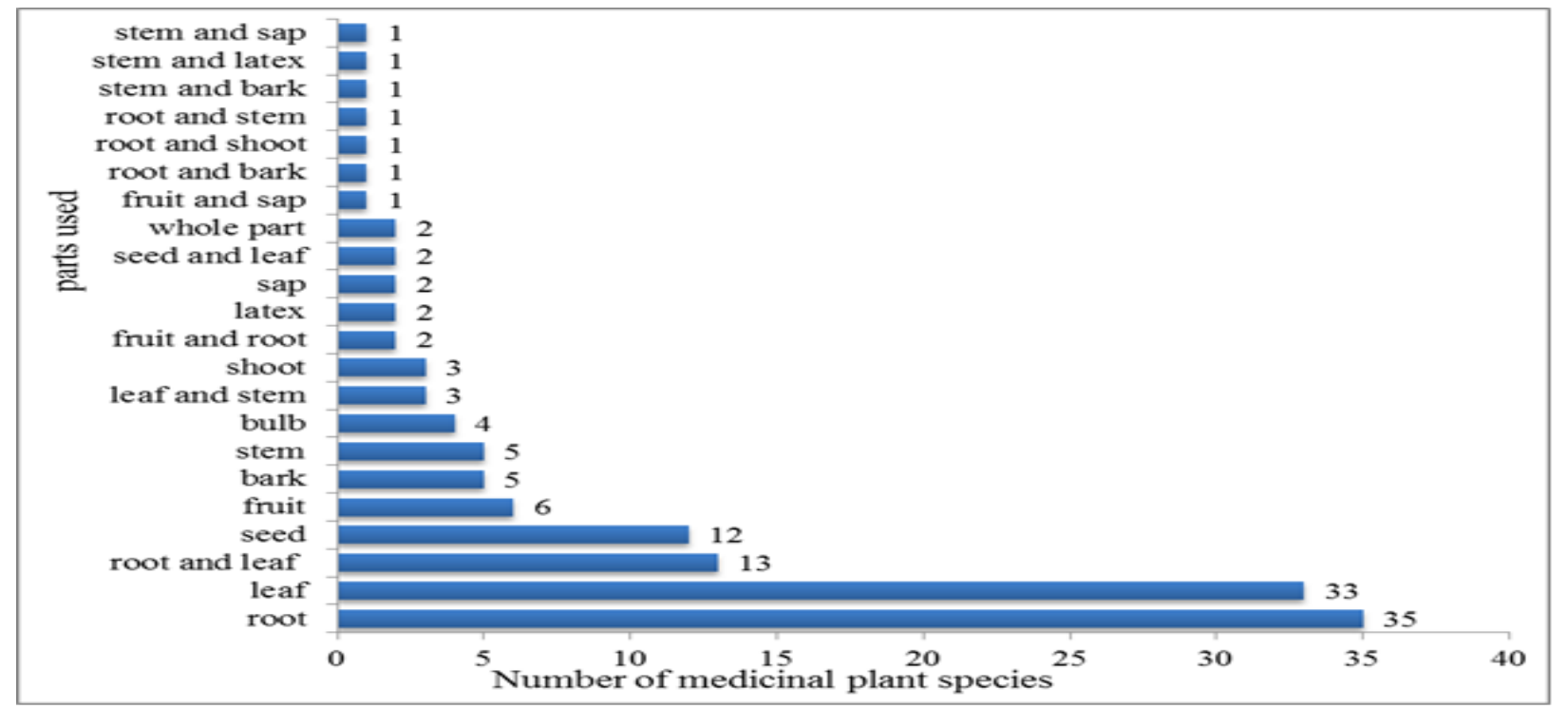

Figure 2: Plant parts used for preparation of medicine in the study area. 
In Hidabu Abote district, different modes of preparation were used to treat human and livestock aliments. The major modes of preparation were crushing (17.65\%), pounding (16.91\%), powdering (13.97\%), squeezing (5.88\%), chewing $(5.15 \%)$, pounding and powdering $(4.41 \%)$ (Figure 3). This is similar with the works of Yirga (2010) that most of the preparation was done by crushing. The preparation and application methods vary based on the types of diseases treated and the actual site of ailments. The majority of the preparations were made from the mixtures of plant species with water and different additive substances like honey, sugar, butter, salt and milk. different These additive substances have different functions such as reduce poisons, improve flavor and as antidotes during adverse effects such as vomiting, skin rash and diarrhea.

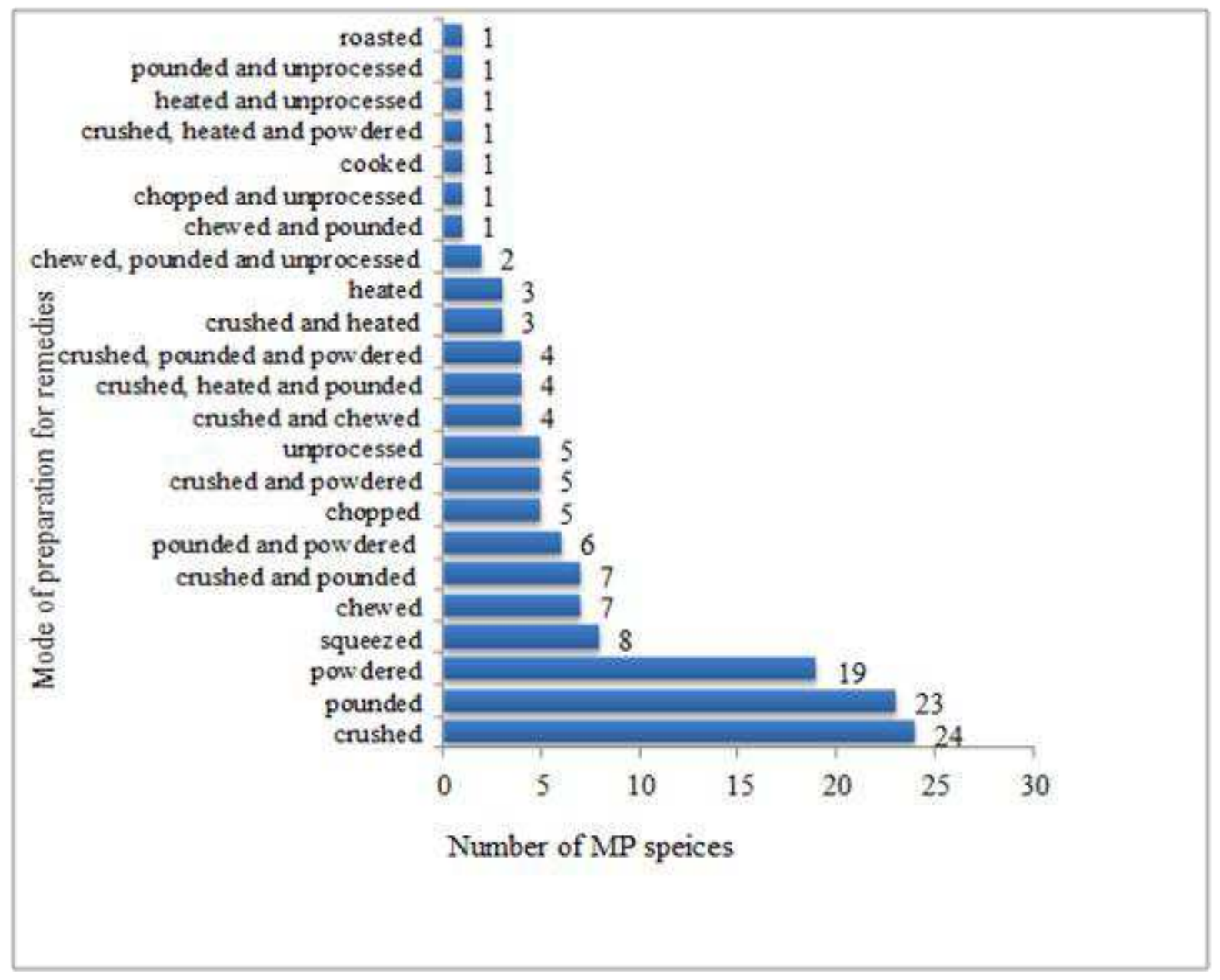

Figure 3: Mode of preparation of medicine to treat both human and livestock in the study area There were various routes of administration of herbal remedies to treat human and livestock aliments. The major routes of administration used in the study area were oral only (30.88\%), dermal only (14.71\%), nasal and dermal (11.76\%), nasal only (8.09\%), dermal and oral (5.88\%), dermal, nasal and oral (4.41\%) (Figure 4). Oral application of remedies was popular as others finding reported by (Mesfin et al., 2009; Zerabruk and Yirga, 2012; Alebie and Mehamed, 2016). Both oral and dermal routes permit quick physiological reaction of the prepared medicines with 
the pathogens and increase their curative powers.

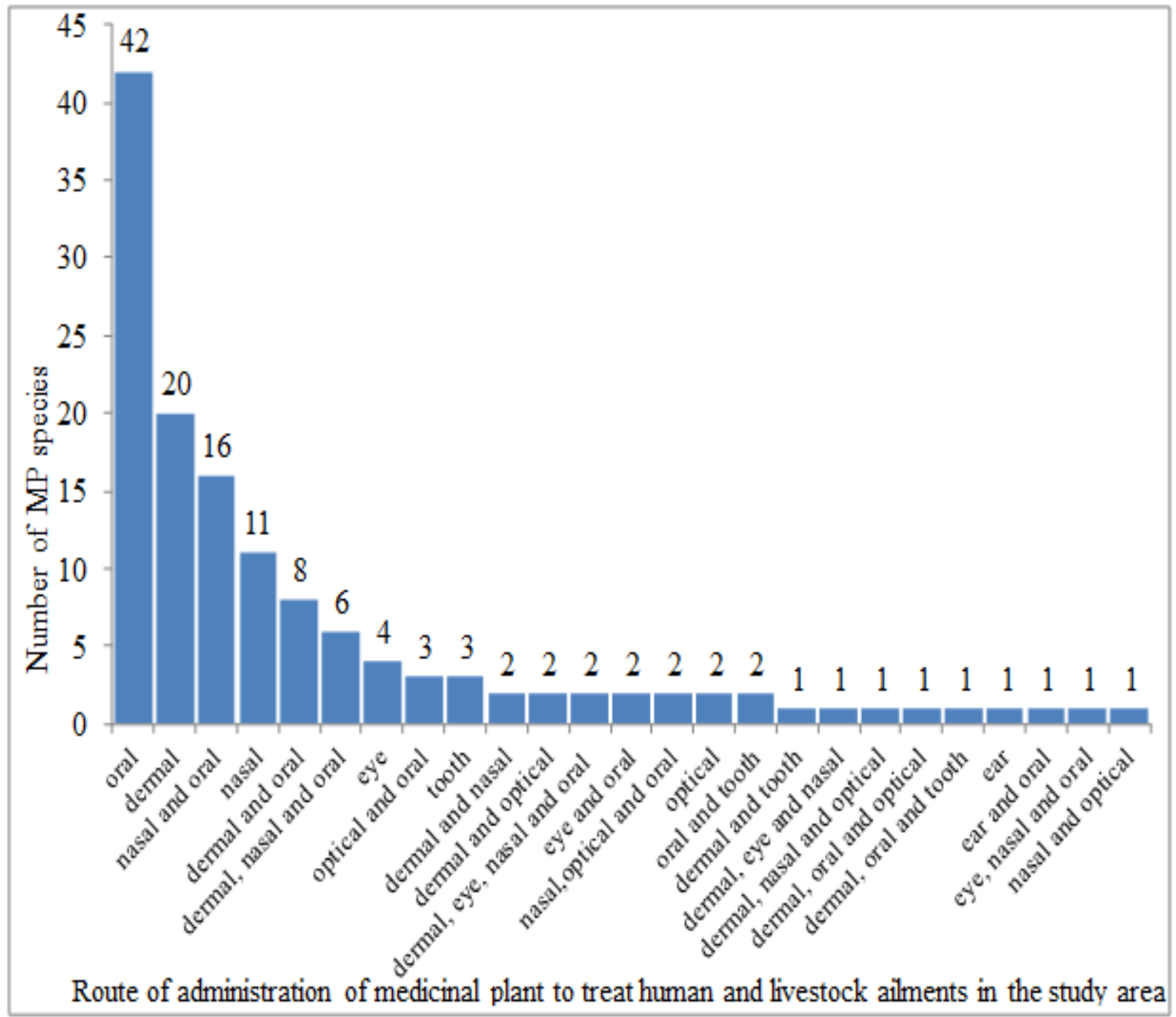

Figure 4: Route of administration of medicine to treat human and livestock ailments in the study area The conditions of preparation of medicinal plants for remedies in the study area were fresh (71 species, 52\%), dry (37 species, 27\%) and fresh or dry (28 species, 21\%). This finding similar with other ethnobotanical studies in Ethiopia by Yineger et al. (2007); Mohammed et al. (2016), that most of medicinal plant species prepared in fresh condition. The frequent use of freshly processed remedies could imply the accessibility of medicinal plants in the locality and high curative power of fresh preparations. 
In the Hidabu Abote district different units of measurements and the duration of administration used to determine the dosage. There is no uniformity with regard to the dosage of the medicine between the different traditional healers and local peoples (use by themselves) for same disease, though all the traditional healers and local peoples agree on the point that the dosage given for patients vary with age and physical strength. They do also agree that some medicines are not allowed to be taken by women when pregnant. Amounts to be administered will be estimated by the use of measurements such as length of a finger, coffee and tea cup, and number count. Recovery from the disease, which usually is determined by the disappearance of disease symptoms, is a criterion that the local peoples of the study area consider to determine the duration of using the medicine. This agrees the other ethnobotanical studies in Ethiopia Lulekal et al. (2008); Kalu and Seid (2014) that the major drawback in practicing traditional medicinal plant for human and livestock aliments is lack of precision and standardization.

\section{Distribution of knowledge of medicinal plants among local peoples}

A Pearson correlation test indicated a positive and significant $(r=0.409, p<0.001$ and $\alpha=0.05)$ correlation between age group and the number of medicinal plant species reported by the household respondents in the study area. Similar finding were reported by (Zenebe et al., 2012; Kebede et al., 2016). This indicates that as age increases the more number of medicinal plant species reported. The likely reasons behind that as age increase they accumulate different knowledge on medicinal plants and young generations were not found to use of medicinal plants as their parents and grandparents.

A Pearson correlation test indicated a negative and significant $(r=-0.299, p<0.001$ and $\alpha=0.05)$ correlation between a level of education and the number of species reported by the household respondents in the study area similar finding with (Zenebe et al., 2012; Kebede et al., 2016). The finding indicates that as the more the person is educated the less number of medicinal plant species were mentioned. The likely reason behind that educated people not prefers to use traditional medicine rather they prefers modern medicine.

The average number of medicinal plants reported by males was $4.97 \pm 3.38$ whereas that of females was $2.90 \pm 1.52$ (mean $\pm \mathrm{SD}$ ). There was significant difference between male and female in their knowledge of medicinal plants $(t=2.767$ and $p<0.009)$. The average number of

medicinal plants reported by key informants was $9.85 \pm 3.18$, while that of household respondents was $4.60 \pm 3.22$ (mean $\pm \mathrm{SD}$ ). There was significant difference between number of medicinal 
plants reported by key informants and household respondents $(t=6.72$ and $p<0.001)$. In the study area gender was a factor for distribution of medicinal plant knowledge, and informant category (key informants and household respondents) was a major factor connected to number of medicinal plants reported. Key informants have greater knowledge on medicinal plants. The finding was in line with the study of conducted by (Lulekal et al., 2013).

Table: Knowledge distribution between gender and informants

\begin{tabular}{lllllll} 
Variables & & $\mathrm{N}$ & Mean of medicinal plant & t-value & df & p-value \\
\cline { 2 - 7 } Gender & Male & 92 & $4.97 \pm 3.38^{\mathrm{a}}$ & 2.67 & 110 & 0.009 \\
& Female & 20 & $2.90 \pm 1.52^{\mathrm{b}}$ & & & \\
Informant & Household & & & & & \\
experience & informant & 112 & $4.60 \pm 3.22^{\mathrm{a}}$ & 6.67 & 130 & 0.001 \\
& Key informant & 20 & $9.85 \pm 3.18^{\mathrm{b}}$ & & & \\
\hline
\end{tabular}

Significant difference $(p<0.05), \alpha=0.05$, different superscript indicates mean difference

\section{Informant consensus}

In Hidabu Abote district medicinal plants which were popular due to the wide range of diseases they treat and commonly used by the local peoples and traditional healers. Certain species were independently cited by many of the informants for their medicinal uses to treat human and livestock ailments. The results of the study showed that some medicinal plants were popular than others and highest informant consensus goes to Ocimum lamiifolium was cited by 31 informants (27.68\%) that agrees with work reported by (Getaneh and Girma, 2014). The popularity of this medicinal plant was due to the preference of the species for treating febrile illness in the community. Otostegia integrifolia cited by 29 informants (25.89\%), Lepidium sativum cited by 23 informants (20.54\%), Croton macrostachyus cited by 22 informants (19.64\%), Justicia schimperiana cited by 19 informants (16.96\%) and Allium sativum cited by 15 informants (13.39\%). Popularity of those medicinal plants was due to access as a result everybody had the chance to see the treatment with minimum secrecy of plants.

\section{Informant consensus factors (ICF)}

Diseases treated by medicinal plants reported in Hidabu Abote district were grouped into different categories based on the site of occurrence of the disease, condition of the disease as well as treatment resemblance of the disease. The informant consensus factors were calculated for each category. In this study, the informant consensus of medicinal plant usage resulted in ICF ranging from 0.51 to 0.84 per disease category. 
The ailments Anemia scored the highest value (0.84) followed by livestock diseases other than cattle diseases where scored the second highest value (0.81). This similar with finding of (Tugume et al., 2016) that Anemia disease scored highest ICF. This indicates that informants use relatively few taxa to manage specific disease conditions as well as consistency in the use of plant species. In this study the lower ICF value was scored (0.51) for the category of diseases like Stomach related diseases. This category may be indicative for lack of consistency in the use of medicinal plant species in the study area.

\section{Preference ranking of human and livestock disease}

When there are different species prescribed for the same health problem, people show preference of one over the other. Preference ranking of 7 medicinal plants that were reported for treating febrile illness human disease and 7 medicinal plants that were reported for treating blackleg livestock disease were conducted after selecting 10 key informants separately. Febrile illness was most frequently reported human disease in the study area. The key informants were asked to compare the given medicinal plants based on their efficacy, and to give the highest number (7) for the medicinal plant which they believed most effective in treating febrile illness and the lowest number (1) for the least effective medicinal plant in treating febrile illness. Ocimum lamiifolium which scored 57 and ranking first indicating that it was most effective in treating febrile illness and followed by Otostegia integrifolia which scored 52 and ranking second; the least effective was Allium sativum. Similar finding was reported by Kassa et al. (2016) that Ocimum lamiifolium ranked first to treat fever human disease and Croton macrostachyus scored 45 and ranking first indicating that it was most effective in treating blackleg and followed by Embelia schimperi which scored 34 and ranking second; the least effective was Solanum incanum. Limenih et al., (2015) also reported that Croton macrostachyus ranked first to treat malaria disease.

\section{Direct matrix ranking}

In Hidabu Abote district, the majority of the peoples rely on wild plants for various purposes such as construction, fencing, firewood, furniture and medicine. To evaluate the relative importance and to check the major impact on such plants direct matrix ranking was performed. In the area, a number of medicinal plants were found to be multipurpose species being utilized for a variety of uses.

Seven most reported multipurpose species and six use categories were involved in direct matrix ranking with 10 key informants. Respondents evaluate their relative importance to the local 
peoples and the extent of the existing threats related to their use values.

The results of the direct matrix ranking revealed that Cordia africana ranked first and hence it was the most preferred plant by local peoples for various uses and the most threatened species as the key informants reported, which was evidently shown by its scarce distribution in the area. This scarcity of Cordia africana was due to over harvesting for not only medicinal but also for other uses such as furniture and firewood mostly. This finding is in line with Teklay (2015) that Cordia africana was most preferred multipurpose plants. Ficus vasta, Croton macrostachyus, Eucalyptus globulus, Olea europaea cuspidata, Juniperus procera and Afrocarpus falcatus ranked $1^{\text {st }}, 2^{\text {nd }}, 3^{\text {rd }}, 4^{\text {th }}, 5^{\text {th }}$ and $6^{\text {th }}$ respectively. So, the top ranked species were highly threatened that there was high rate of loss of Cordia africana in the study area.

\section{Threat and conservation of medicinal plants}

Factors threatening medicinal plants are caused by anthropogenic and natural causes. Household respondents reported that natural factor such as droughts are the major challenges. The medicinal plants threatened by human induced factors such as overgrazing, agricultural expansion, pesticide application on farmland and introduction exotic plants (such as Eucalyptus globulus Plantation). Humans utilize medicinal plant species to satisfy their needs for different purposes (firewood, construction, fencing and furniture), such as over use of medicinal plant species cause damage to survival of medicinal plants.

Based on respondents perception agricultural expansion (41.96\%) stands first to be a threatening factor of medicinal plants in the study area, followed by firewood collection (33.04\%) and overgrazing (25.00\%). This finding agrees with Bekele and Reddy (2015); Birhanu et al. (2015) that agricultural expansion was the most common threatening factors to medicinal plants, followed by firewood and overgrazing. Agricultural expansion was found the highest threatening factor since there is an increasing in population.

\section{Conservation of medicinal plants}

Different conservation practices were reported to be practiced by local peoples in the study area aiding for continuity of medicinal plants and associated indigenous knowledge. Ex-situ conservation such as plantation of medicinal plants in homegarden and seed storage, and In-situ conservation such as limiting grazing by livestock ${ }^{\text {ee }} \mathrm{s}$ and pruning branches of species regenerate themselves by pruning (i.e. Afrocarpus falcatus) was practiced by local peoples. Currently forests are being conserved by efforts of the community and the government around the Jema valley, Sire forest and Deka Bora forest incase wild medicinal plants was also conserved. 


\section{CONCLUSION}

In Hidabu Abote district several plants are used for medicinal purposes. As compared to other studies much number of medicinal plants and associated indigenous knowledge were reported to be used in study area for human and livestock aliments. The highest numbers of medicinal plants were used in Sire Morose kebele (midland), but collection was not restricted only to their locality the move other kebeles to harvest medicinal plants.

In the study area elders have better knowledge of medicinal plant than younger, while there was negative and significant difference between level of education and number of medicinal plant species cited. There was significant difference between male and female informants in their knowledge of medicinal plants, and also there was also a significant difference was found between number of medicinal plants reported by key informants and household respondents.

Agricultural expansion, firewood collection, construction, fencing, furniture, drought and charcoal were threatening medicinal plants in the study area. Local peoples were practicing exsitu and in-situ conservation to decrease degradation of medicinal plants from the study area.

\section{Declarations}

\section{Ethics approval and consent to participate}

This Study approved from Hawassa University, Ethiopian Biodiversity Institute and District administration office.

\section{Consent for publication}

Not applicable

\section{Available data and Materials}

Additional information file 1: table 1: List of medicinal plants in the study area; with Botanical name, family, local name, habit, habitat, condition of preparation, disease treated, parts used, mode of preparations, and route of administration.

Additional information file 2: Table 2: List of Local and botanical name of human and livestock diseases.

\section{Funding}

Hawassa University and Madda Walabu University supported this study during data collection.

\section{Competing interests}

The authors declare that they have no competing interests.

\section{Authors' contributions}

Boja Tilinti is collected primary data, identified the species, analyzed and interpreted the data, and write the manuscript. Yoseph Melka is commenting data analysis, and has involved in preparation of the manuscript. Tesfaye Awas is contribute in the species identification, and commenting on data analysis and the draft 
manuscript. All the authors read and approved the final manuscript.

\section{Acknowledgements}

We would like to thanks Wondo Genet College of forestry and natural resource for providing us field materials.

Our heartily acknowledgment goes to the Ethiopian Biodiversity Institute allowing us use facilities to identify plant specimens. We would like to express deepest thanks the local people of Hidabu Abote Districts for their kindness in providing me information on the medicinal plants and Jima Desta for his help in data collection.

\section{REFERENCES}

Abebe, D. and Ayehu, A., 1993. Medicinal plants and enigmatic health practices of Northern Ethiopia.

Alebie, G. and Mehamed, A., 2016. An ethno-botanical study of medicinal plants in Jigjiga town, capital city of Somali regional state of Ethiopia. International Journal of Herbal Medicine, 4(6), pp.168-175.

Awas, T. and Demissew, S., 2009. Ethnobotanical study of medicinal plants in Kafficho people, southwestern Ethiopia. In Proceedings of the 16th International Conference of Ethiopian Studies (Vol. 3, pp. 711-726). NTNU-Trykk Press Trondheim, Norway.

Awas, T., 2007. Plant diversity in Western Ethiopia: ecology, ethnobotany and conservation. PhD Dissertation, Faculty of Mathematics and Natural Sciences, University of Oslo, Norway.

Bekele, E., 2007. Study on actual situation of medicinal plants in Ethiopia. Addis Ababa: Prepared for Japan Association for International Collaboration of Agriculture and Forestry.

Bekele, G. and Reddy, P.R., 2015. Ethnobotanical Study of Medicinal Plants Used to Treat Human Ailments by Guji Oromo Tribes in Abaya District, Borana, Oromia, Ethiopia. Universal Journal of Plant Science, 3(1), pp.1-8.

Birhanu, T., Abera, D., Ejeta, E. and Nekemte, E., 2015. Ethnobotanical study of medicinal plants in selected Horro Gudurru Woredas, western Ethiopia. Journal of Biology, Agriculture and Healthcare, 5(1), pp.83-93.

Birhanu, Z., 2013. Traditional use of medicinal plants by the ethnic groups of Gondar Zuria District, North-Western Ethiopia. Journal of Natural Remedies, 13(1), pp.46-53.

Cotton, C.M., 1996. Ethnobotany: principles and applications. John Wiley \& Sons. Chichester, Pp. 242.

Dawit, A., 2001, April. The Role of Medicinal Plants in Healthcare Coverage of Ethiopia, the possible integration. In Proceeding of the National work shop on 
Conservation and Sustainable Use of Medicinal Plants in Ethiopia (Vol. 28, pp.6-21).

Enyew, A., Asfaw, Z., Kelbessa, E. and Nagappan, R., 2014. Ethnobotanical study of traditional medicinal plants in and around Fiche District, central Ethiopia. Current Research Journal of Biological Sciences, 6(4), pp.154-167.

Espinosa, M.M., Bieski, I.G. and Martins, D.T.D.O., 2012. Probability sampling design in ethnobotanical surveys of medicinal plants. Brazilian Journal of Pharmacognosy, 22(6), pp.1362-1367.

Fenetahun, Y. and Eshetu, G., 2017. A review on ethnobotanical studies of medicinal plants use by agro-pastoral communities in, Ethiopia. Journal of Medicinal Plants, 5(1), pp.33-44.

Getaneh, S. and Girma, Z., 2014. An ethnobotanical study of medicinal plants in Debre Libanos Wereda, Central Ethiopia. African Journal of Plant Science, 8(7), pp.366-379.

Heinrich, M., Ankli, A., Frei, B., Weimann, C. and Sticher, O., 1998. Medicinal plants in Mexico: Healers' consensus and cultural importance. Social Science \& Medicine, 47(11), pp.1859-1871.

Hidabu Abote District Agricultural and Natural Resources Office(HADANRO), 2016. Hidabu Abote District Agricultural and Rural Development Office.

Institute of Biodiversity Conservation, 2005. National Biodiversity Strategy and Action plan. Addis Ababa Ethiopia, Pp.115.

Kalu, D. and Seid, A., 2014. Ethnobotanical study of Medicinal plants in Ankober woreda, central Ethiopia. Ethiopian Journal of Science and Technology, 7(2), pp.105-114.

Kassa, Z., Asfaw, Z. and Demissew, S., 2016. Ethnobotanical study of medicinal plants used by the local people in Tulu Korma and its Surrounding Areas of Ejere District, Western Shewa Zone of Oromia Regional State, Ethiopia. Journal of Medicinal Plants, 4(2), pp.24 47.

Kebebew, M., 2016. Knowledge of medicinal plants used in and around Fincha'a Town, Western Ethiopia. Journal of Pharmacognosy and Phytochemistry, 5(6), p.110.

Kebede, A., Ayalew, S., Mesfin, A. and Mulualem, G., 2016. Ethnobotanical investigation of traditional medicinal plants commercialized in the markets of Dire Dawa city, eastern Ethiopia. Journal of Medicinal Plants, 4(3), pp.170-178.

Limenih, Y., Umer, S. and Wolde-Mariam, M., 2015. Ethnobotanical study on traditional medicinal plants in Dega Damot Woreda, Amhara region, north Ethiopia. IJRPC, 5, pp.258-273.

Lulekal, E., Asfaw, Z., Kelbessa, E. and Van Damme, P., 2013. Ethnomedicinal study of plants used for human ailments in Ankober District, North Shewa Zone, Amhara region, Ethiopia. Journal of ethnobiology and ethnomedicine, 9(1), p.63.

Lulekal, E., Kelbessa, E., Bekele, T. and Yineger, H., 2008. An ethnobotanical study of medicinal plants in Mana Angetu District, southeastern Ethiopia. Journal of ethnobiology and Ethnomedicine, Pp.10.

Martin, G., 1995. Ethnobotany: a methods manual, Chapman y Hall. Nowy Jork.

Mesfin, F., Demissew, S. and Teklehaymanot, T., 2009. An ethnobotanical study of medicinal plants in Wonago Woreda, SNNPR, Ethiopia. Journal of Ethnobiology and Ethnomedicine, 5(1), p.28.

Mohammed, C., Abera, D., Woyessa, M. and Birhanu, T., 2016. Survey of ethno-veterinary medicinal plants in Melkabello District, Eastern Harerghe Zone, Eastern Ethiopia. Ethiopian Veterinary Journal, 20(2), pp.1-15.

Okello, S.V., Nyunja, R.O., Netondo, G.W. and Onyango, J.C., 2010. Ethnobotanical study of medicinal plants used by Sabaots of Mt. Elgon Kenya. African Journal of Traditional, Complementary and Alternative Medicines, 
Phondani, P.C., Bhatt, A., Elsarrag, E. and Horr, Y.A., 2016. Ethnobotanical magnitude towards sustainable utilization of wild foliage in Arabian desert. Journal of Traditional and Complementary Medicine, 6(3), pp.209-218.

Tadesse, M., Hunde, D. and Getachew, Y., 2005. Survey of medicinal plants used to treat human diseases in Seka Cherkosa, Jimma Zone, Ethiopia. Ethiopian Journal of Health Sciences, 15(2), pp.89-106.

Tamiru, F., Terfa, W., Kebede, E., Dabessa, G., Roy, R.K. and Sorsa, M., 2013. Ethnoknowledge of plants used in veterinary practices in Dabo Hana District, West Ethiopia. Journal of Medicinal plants Research, 7(40), pp.2960-2971.

Teklay, A., 2015. Traditional medicinal plants for ethnoveterinary medicine used in Kilte Awulaelo District, Tigray Region, Northern Ethiopia. Journal of Biology, Agriculture and Healthcare, 3, pp.137-150.

Tugume, P., Kakudidi, E.K., Buyinza, M., Namaalwa, J., Kamatenesi, M., Mucunguzi, P. And Kalema, J., 2016. Ethnobotanical survey of medicinal plant species used by communities around Mabira Central Forest Reserve, Uganda. Journal of ethnobiology and ethnomedicine, 12(1), p.5.

World Health Organization, 2003. Fact Sheet. Geneva. Family,body, sexuality and health. Pp. 205 - 219. Accessed from internet: http://books.google.com.et/books.

Yineger, H. and Yewhalaw, D., 2007. Traditional medicinal plant knowledge and use by local healers in Sekoru District, Jimma Zone, Southwestern Ethiopia. Journal of Ethnobiology and Ethnomedicine, 3(1), p.24.

Yineger, H., Kelbessa, E., Bekele, T. and Lulekal, E., 2007. Ethnoveterinary medicinal plants at bale mountains national park, Ethiopia. Journal of Ethnopharmacology, 112(1), pp.55-70.

Yirga, G., 2010. Use of traditional medicinal plants by indigenous people in Mekele town, capital city of Tigray regional state of Ethiopia. Journal of Medicinal Plants Research, 4(17), pp.1799-1804.

Zenebe, G., Zerihun, M. and Solomon, Z., 2012. An ethnobotanical study of medicinal plants in Asgede Tsimbila district, Northwestern Tigray, northern Ethiopia. Ethnobotany Research and Applications, 10, pp.305-320.

Zerabruk, S. and Yirga, G., 2012. Traditional knowledge of medicinal plants in Gindeberet district, Western Ethiopia. South African Journal of Botany, 78, pp.165-169 


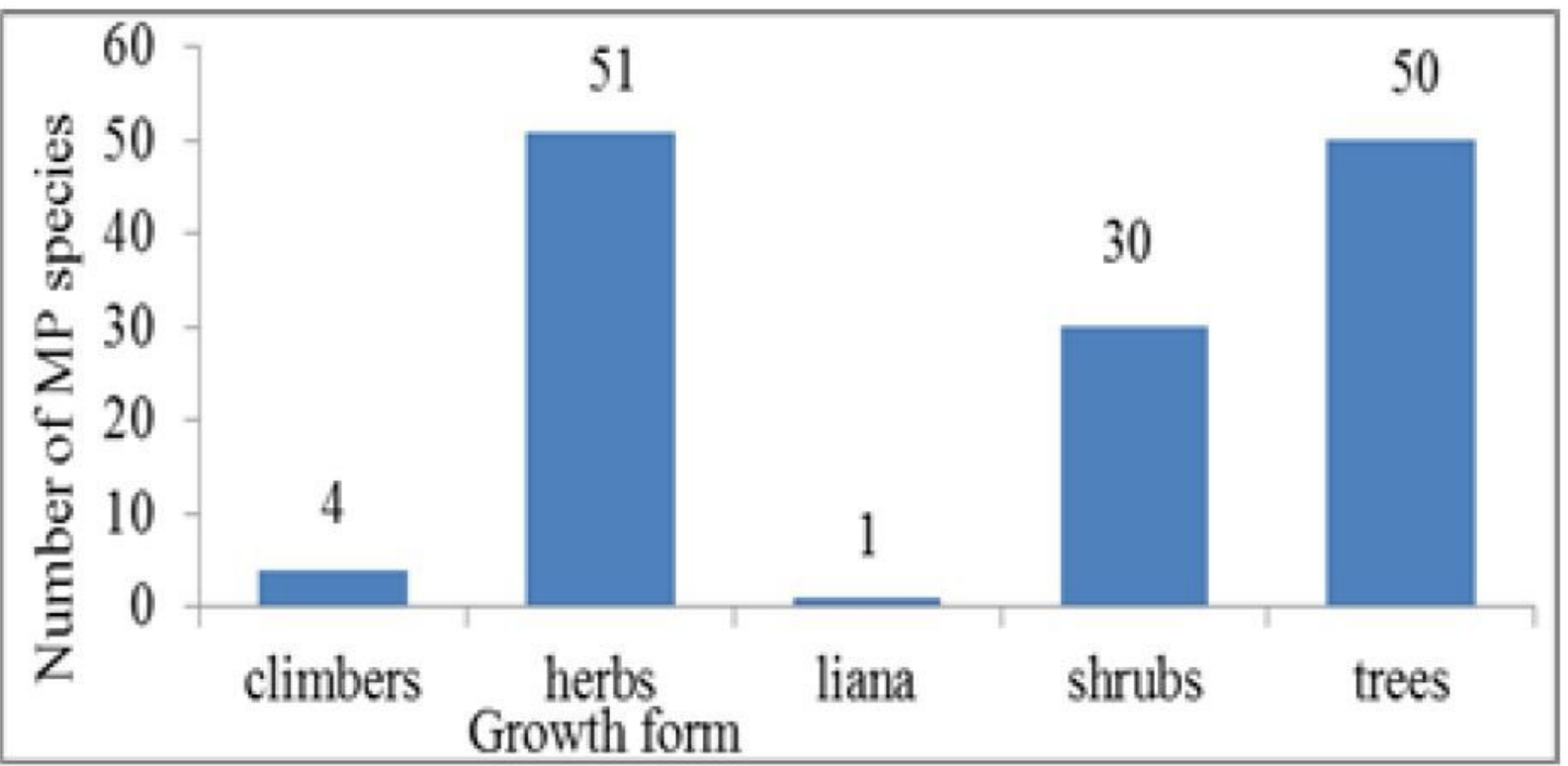

Figure 1

Growth form of MPs in the study area

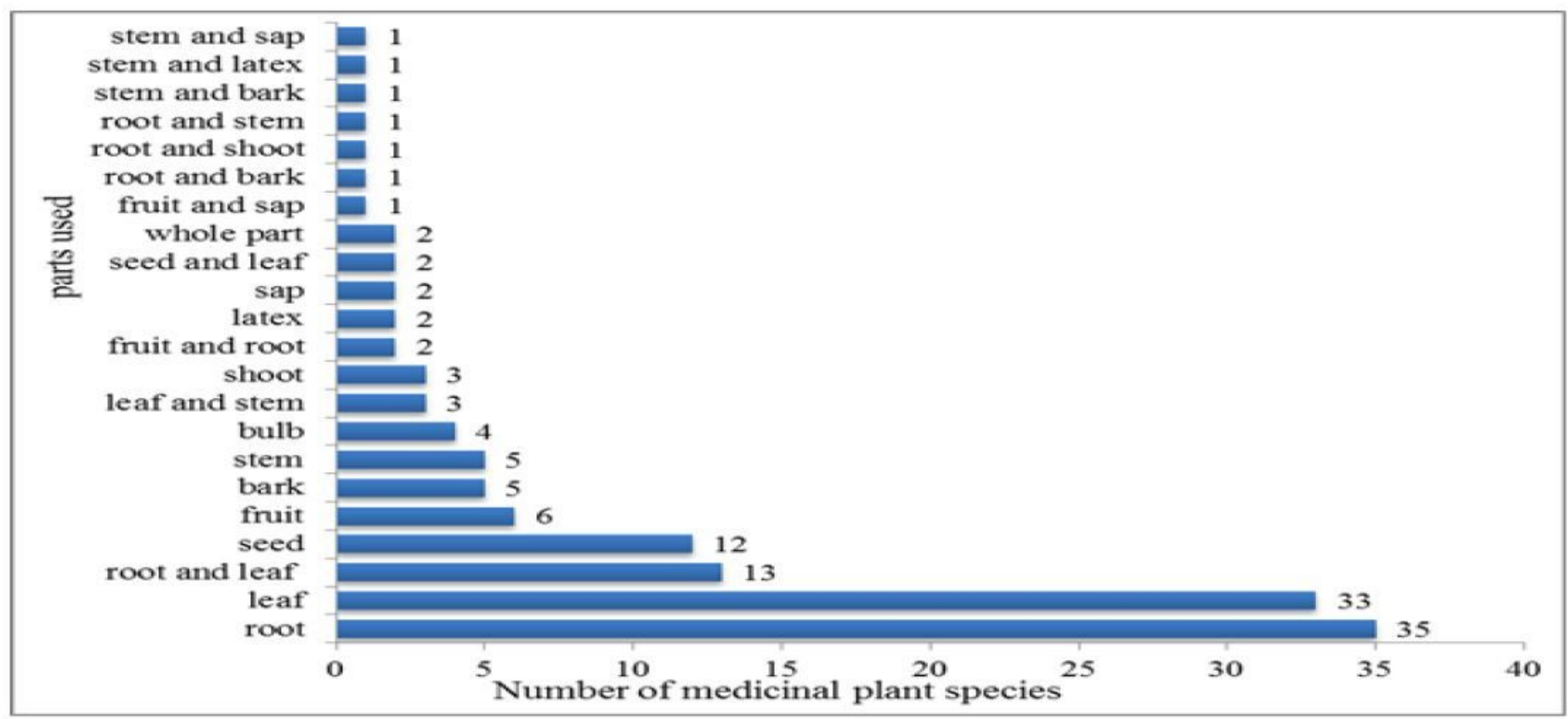

Figure 2

Plant parts used for preparation of medicine in the study area. 


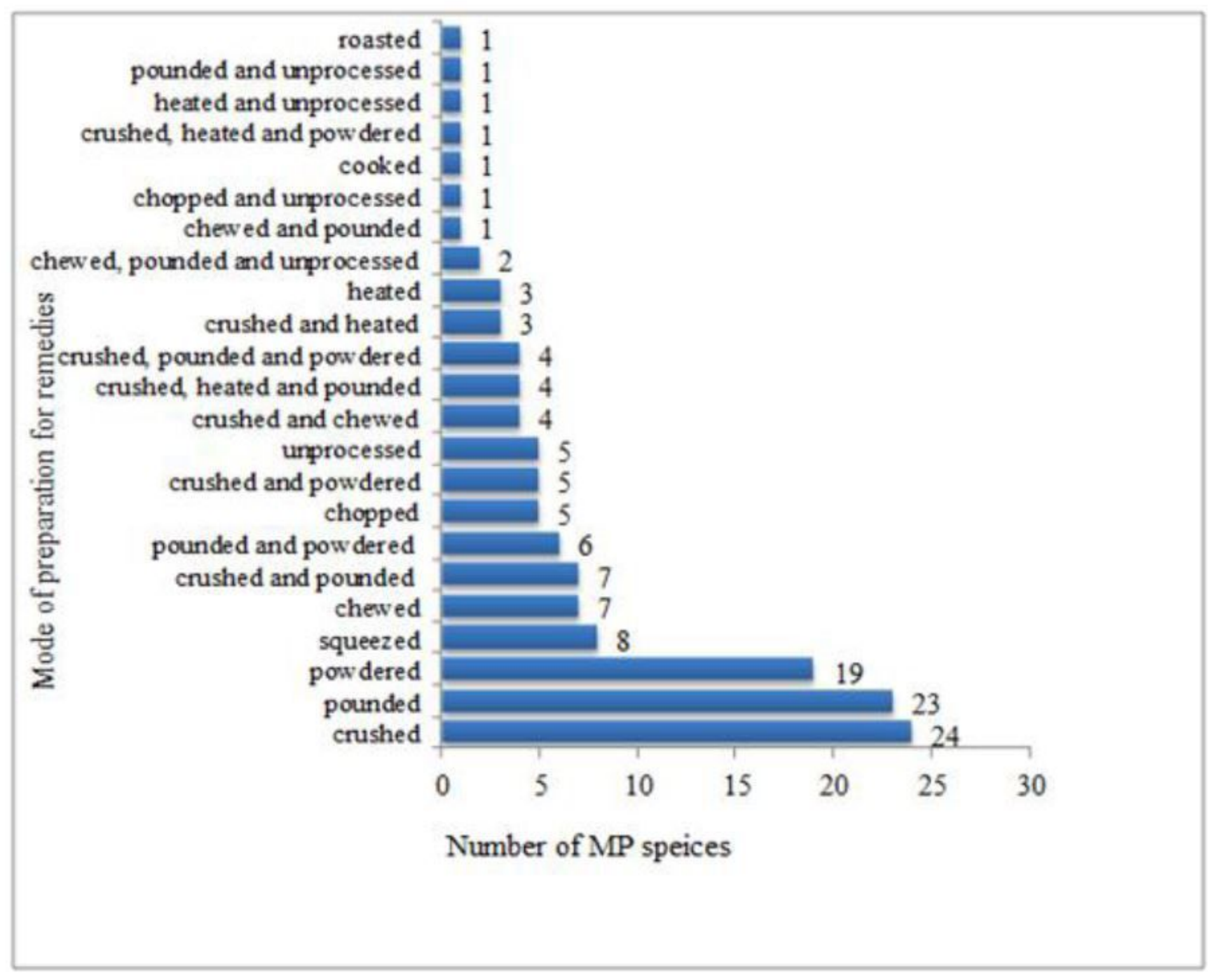

Figure 3

Mode of preparation of medicine to treat both human and livestock in the study area 


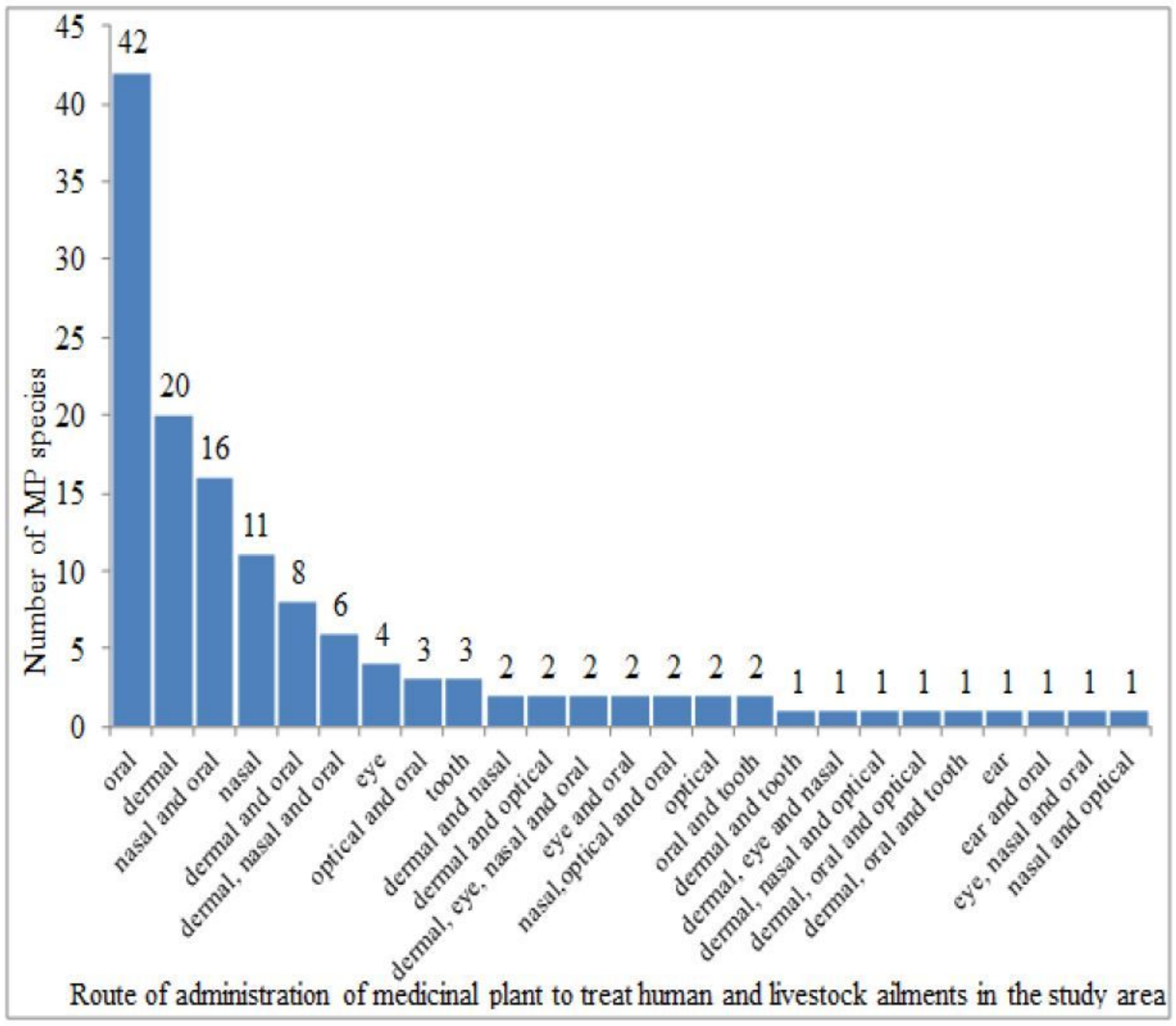

\section{Figure 4}

Route of administration of medicine to treat human and livestock ailments in the study area

\section{Supplementary Files}

This is a list of supplementary files associated with this preprint. Click to download.

- Table1listofmedicinalplants.pdf

- Table2diseasename.pdf

- Figure.jpg 